\title{
Discussion on the Education Mode of Innovation and Entrepreneurship in Chinese Colleges and Universities
}

\author{
Liu Xiao \\ Xijing University, Xi'an, Shaanxi, China, 710123
}

Keywords: Chinese colleges and universities; innovation and entrepreneurship; mentor construction

\begin{abstract}
The innovation and entrepreneurship of Chinese college students has become a big trend. The building of innovation and entrepreneurship mentor team is an important foundation of innovation and entrepreneurship education, which plays an important role in promoting the innovation and entrepreneurship of Chinese college students. So, it is of practical significance to analyze and study the construction of innovation and entrepreneurship mentor team. This paper elaborates on the foundation of the construction of innovation and entrepreneurship mentor team and analyze the problems in the innovation and entrepreneurship mentor team in most Chinese colleges and universities. In the end, this paper provides opinions on the construction of innovation and entrepreneurship mentors in Chinese colleges and universities and improves the quality of innovation and entrepreneurship education.
\end{abstract}

\section{Introduction}

With the slogan of "National entrepreneurship and innovation ", the trend of college students' innovation and entrepreneurship is unstoppable. Education is the key to promote innovation and entrepreneurship, and a professional team of innovative and entrepreneurial mentors has a great impact on the entrepreneurship of college students. The tutor team is the first resource for the innovation and entrepreneurship of college students, and it is also an important factor for guiding and guiding the success of college students. We should cultivate and build a team of Chinese university mentors to promote the success of college students' innovation and entrepreneurship. So, we must attach importance to the active role of innovation and entrepreneurship tutor to college students.

\section{The Foundation of the Construction of Innovation and Entrepreneurship Mentor Team}

\subsection{The "double energy" mentor is an opportunity for the team building.}

"Double energy" teacher refers to the tutor who undertakes the applied science research while undertaking undergraduate teaching in the university. The construction of China's innovation and entrepreneurship tutor team also requires the tutor to undertake other teaching tasks while undertaking the innovation and entrepreneurship guidance of college students. So, the construction of "double-energy" team provides an opportunity for the construction of innovation and entrepreneurship mentor team. And it provides a solid guarantee for the innovation and entrepreneurship tutor team.

\subsection{Thick education atmosphere provides the environment for the team building.}

There is a big difference between the pace and achievements of Chinese universities in building innovative entrepreneurial mentors. However, universities in China have created a strong atmosphere of innovation and entrepreneurship education, and actively carry out the education activities. University entrepreneurship education is also supported by the parents of college students. It also provides support to college students through their own family, and even some parents are directly involved in innovation and entrepreneurship activities. This kind of strong innovation and 
entrepreneurship education atmosphere provides the environment for the establishment of tutors in universities.

\subsection{Government support provides the direction for the team building.}

The Chinese government has provided a lot of policy documents to support the innovation and entrepreneurship of college students. At the same time, a large number of policies have been issued to support the construction of education innovation and entrepreneurship. For example, the general office of the people's government on the implementation of education reform of innovation and entrepreneurship in institutions of higher learning. The Chinese government has given guidance and direction for management system, performance appraisal, etc. of creating a team of innovative entrepreneurial mentors. The government's support and policy provide a convenient condition for the establishment of a mentor team on the macro guidance and resources.

\section{Problems Existing in the Team of Innovation and Entrepreneurship Mentor}

\subsection{The mentor structure needs to be adjusted.}

The current structure of innovation and entrepreneurship tutors in Chinese universities is mostly part-time and co-existing structure. It is the employment and entrepreneurship education teaching and research office to recruit teachers from all disciplines, and contact entrepreneurs, government officials and successful entrepreneurs to conduct irregular classes or speeches. In these teams, some are teachers or professors working on education, and some are government officials or entrepreneurs who can't work on education. Most of the entrepreneurs and entrepreneurs hired by colleges and universities are not perfect in their incentive, compensation and evaluation system. This has a lot to do with the structure of the mentor. So, Chinese universities should constantly adjust and improve the tutor structure in the process of innovation and entrepreneurship.

\subsection{The weak quality of innovation and entrepreneurship mentors}

There is a lack of innovative entrepreneurs and leaders in most universities in China. This is directly related to the weak foundation of education. With the lack of the backup staff of university tutors and the lack of leaders, it will lead to the lack of promotion of university tutors, which will lead to the slow development of education and cultivation.

\subsection{The mentor team lacks practical experience.}

The teaching force of the innovation and entrepreneurship tutor team in Chinese universities is weak. This weak education status is related to the leaders of its disciplines, and also to the lack of experienced entrepreneurs in the ranks. Most of the innovation and entrepreneurship tutors in universities are formed on the basis of career guidance teachers. Thus, entrepreneurs and entrepreneurs with entrepreneurial experience are not involved. This directly reflects the lack of practical experience of the school mentor team. On the other hand, although there are entrepreneurs and entrepreneurs involved in some universities, they often train students just in the form of regular lectures. And this kind of training that can't form regular training is very difficult to produce a qualified student who has the ability of entrepreneurship.

\section{Improve the Team of Innovation and Entrepreneurship Mentor}

\subsection{Give full play to the role of part-time teachers.}

It is still only in the initial stage that our universities create innovation and entrepreneurship tutors. There is a huge demand for teachers. And there are more entrepreneurs and entrepreneurs in the school's expert library, so there are more part-time teachers in the mentor team. Give full play to the strength and resources of part-time staff in the mentor team, and attract more high-quality entrepreneurial practitioners to serve as part-time teachers. Chinese universities often invite entrepreneurs or successful entrepreneurs from their alumni to serve as entrepreneurial mentors, and 
give lectures or training to students on a regular or irregular basis. Schools enrich students' experience and experience in this way. For example, the "Entrepreneurship senior Plan of the Chinese university of Hong Kong. It is the plan that serves as the school's entrepreneurial teacher through the senior students who have embarked on the entrepreneurial path after graduating from the school, and has led the students in the school to conduct entrepreneurial training. In this way, schools can promote communication with entrepreneurs and provide resources and network for entrepreneurial students.

\subsection{Diversify the training of mentor team.}

It is inevitable that there will be different quality in the innovation and entrepreneurship tutors. So we need all the members to participate in the system innovation and entrepreneurship training for enhancing the overall strength of the team. To be a qualified innovation and entrepreneurship mentor, you must have the professional quality and profound knowledge of the subject and the knowledge of practical experience. Only with rich theoretical foundation and practical experience, you can train students' practical ability and practical ability through their rich experience and practical experience in running the company. You can guide and teach the typical case based on the theoretical basis. Colleges and universities should create a systematic training system for innovation and entrepreneurship. Only tutors trained by the system are qualified to teach students. During the training of the tutor, I can choose the internal centralized training and regular assignment study according to the tutor's schedule.

\subsection{Develop innovation and entrepreneurship education course.}

When innovation and entrepreneurship mentors are teaching and training, we should not only be a communicator of theoretical knowledge, but also should continuously develop and learn new education courses. In the course of the development of entrepreneurship course, the entrepreneur must fully consider the teaching purpose, teaching content and teaching means, etc. Finally, it aims to improve students' interest in learning and to train students' innovative entrepreneurial consciousness and ability. This course is to deepen students' understanding of entrepreneurship and lay the foundation for the later stage of entrepreneurship. The innovation and entrepreneurship mentor must have the ability to update and innovate the education course. By setting up suitable entrepreneurship courses for students of different majors, only in this way can we promote innovation and entrepreneurship education quality, which is the qualified entrepreneur mentor.

\section{Conclusion}

Education is the key to promote innovation and entrepreneurship, and a professional team of innovative and entrepreneurial mentors has a great impact on the entrepreneurship of college students. Cultivating and constructing Chinese university tutors is an important breakthrough to improve college students' innovation and entrepreneurship. So, we must attach importance to the active role of innovation and entrepreneurship tutor to college students. We will build a high-quality teaching team by combining the training mode of the double-energy teacher and the construction of innovation and entrepreneurship tutor team.

\section{References}

[1] Barbara J. Bird, David N. Allen. "Faculty Entrepreneurship in Research University Environment. Journal of Higher Education (1989), p. 586-587

[2] Murray B. Low Ian. C. Mae Millan. Entrepreneurship: Past Rese are hand Future Challenges Journal of Management. Higher Education (2003), p. 139 - 161

[3] Zaghloul Morsy \& Philip G. Altbach. Higher Education in an International Perspective: Critical Issues, Garrland Publishing, Inc. New York \& London (1996), p. 153.

[4] Hurd, P.D. Scientific Literacy: New Minds for Changing World. Science Education (2008), p. 
407-416

[5] Beyer, C.H, Gilinore, G.M., Fisher, A.T. Inside the Undergraduate Experience: The University of Washington's Study of Undergraduate Learning. Bolton: Anker, Publishing Company (2007), p. 32-35

[6] Semra Guven. World Conference on Edueational Seiences New primary edueation course programmes and entrepreneurship. Proeedia Social and Behavioral Seiences (2009), p. 265-270

[7] Helge Berglann; EsPenR. Moen, KnutRoed, etal . EntrePreneurshiP: Originsandreturns. Labour Eeonomies (2011), p. 180-193

[8] Roediger Voss. Thorsten Gruberjsabelle Szmigin."Service quality in higher education: Therole of student expectations”. Journal of Business- Research (2007), p. 949-959 